Columbia Law School

Scholarship Archive

\title{
Toward Supranational Copyright Law? The WTO Panel Decision and the "Three-Step Test" for Copyright Exceptions
}

Jane C. Ginsburg

Columbia Law School, jane.ginsburg@law.columbia.edu

Follow this and additional works at: https://scholarship.law.columbia.edu/faculty_scholarship

Part of the Intellectual Property Law Commons, and the Torts Commons

\section{Recommended Citation}

Jane C. Ginsburg, Toward Supranational Copyright Law? The WTO Panel Decision and the "Three-Step Test" for Copyright Exceptions, ReVue InTERNATIONALE du Droit d'AUTEUR, Vol. 187, P. 3, 2001; Columbia LaW \& Economics Working Paper No. 181; Columbia Public Law Research Paper No. 19 (2001).

Available at: https://scholarship.law.columbia.edu/faculty_scholarship/1235

This Working Paper is brought to you for free and open access by the Faculty Publications at Scholarship Archive. It has been accepted for inclusion in Faculty Scholarship by an authorized administrator of Scholarship Archive. For more information, please contact scholarshiparchive@law.columbia.edu. 


\title{
Columbia Law School
}

The Center for Law and Economic Studies

Working Paper No. 181

Public Law \& Legal Theory Research Paper Group

Paper Number 19

\section{Toward Supranational Copyright Law? The WTO Panel Decision and the “Three-Step Test” for Copyright Exceptions}

\author{
Jane C. Ginsburg \\ Columbia University \\ School of Law
}

January, 2001

Forthcoming in Revue Internationale du Droit d'Auteur, January 2001

This paper can be downloaded without charge from the Social Science Research Network electronic library at: http://papers.ssrn.com/paper.taf?abstract id=253867

An index to the working papers in the Columbia Law School Working Paper Series is located at: http://www.law.columbia.edu/lawecl 
For Revue Internationale du Droit d'Auteur, January 2001

\title{
TOWARD SUPRANATIONAL COPYRIGHT LAW? THE WTO PANEL DECISION AND THE “THREE-STEP TEST” FOR COPYRIGHT EXCEPTIONS
}

\author{
Jane C. Ginsburg, Professor, Columbia University School of Law ${ }^{1}$
}

\begin{abstract}
A dispute resolution panel of the World Trade Organization in June 2000 held the United States in contravention of its obligation under art. 13 of the TRIPs accord to

" confine limitations or exceptions to exclusive rights to certain special cases which do not conflict with a normal exploitation of the work and do not unreasonably prejudice the legitimate interests of the right holder." In the dispute resolution proceeding, initiated by the European Union at the behest of the Irish performing rights organization, the contested exception, enacted in the 1998 "Digital Millennium Copyright Act," exempted a broad range of retail and restaurant establishments from liability for the public performance of musical works by means of communication of radio and television transmissions.
\end{abstract}

The WTO panel decision marks the first time an international adjudicative body has interpreted either art. 13 of TRIPs, or art. 9.2 of the Berne Convention, the text TRIPs incorporates, and generalizes from the Berne Convention reproduction right to all TRIPs and Berne rights under copyright. Berne art. 9.2/TRIPs art. 13 impose the "three-step test" to evaluate the legitimacy of exceptions and limitations on copyright; the panel decision extensively analyzes each of the steps. As other multilateral instruments, such as the 1996 WIPO Copyright Treaty (art. 10) and WIPO Performers and Phonograms Treaty (art. 16.2), as well as the pending European Union Information Society Directive (art. 5.4), increasingly adopt the "three-step test," the WTO Panel decision may significantly advance the development of a truly supra national law of copyright.

This article will analyze the Panel' s interpretation of the test three steps, and their application to the U.S.-law exemption. The article will also compare the Panel treatment of the three-step test with the prior analyses proposed by several Berne Convention commentators, in order to reflect on what the Panel fanalysis might mean for copyright exceptions more broadly. It is important to recognize, however, that the decision actual impact on international copyright law will also depend on other considerations that will not be addressed here, including: Member State compliance with Panel decisions; the precedential effect of one Panel decision on later dispute resolution panels; and the willingness of national courts to look to WTO Panel decisions for guidance in evaluating local exceptions.

${ }^{1}$ Many thanks for helpful discussions to Joanne Oliver (LLB, Victoria University of Wellington, N.Z.), Columbia Law School LLM class of 2001

${ }^{1}$ Many thanks for helpful discussions to Joanne Oliver (LLB, Victoria University of Wellington, N.Z.), Columbia Law School LLM class of 2001. 


\section{Introduction}

A dispute resolution panel of the World Trade Organization in June 2000 held the United States in contravention of its obligation under art. 13 of the TRIPs accord to "confine limitations or exceptions to exclusive rights to certain special cases which do not conflict with a normal exploitation of the work and do not unreasonably prejudice the legitimate interests of the right holder." In the dispute resolution proceeding, initiated by the European Union at the behest of the Irish performing rights organization, the contested exception, enacted in the 1998 "Digital Millennium Copyright Act," exempted a broad range of retail and restaurant establishments from liability for the public performance of musical works by means of communication of radio and television transmissions.

The WTO panel decision marks the first time an international adjudicative body has interpreted either art. 13 of TRIPs, or art. 9.2 of the Berne Convention, the text TRIPs incorporates, and generalizes from the Berne Convention reproduction right to all TRIPs and Berne rights under copyright. Berne art. 9.2/TRIPs art. 13 impose the "three-step test" to evaluate the legitimacy of exceptions and limitations on copyright; the panel's decision extensively analyzes each of the steps. As other multilateral instruments, such as the 1996 WIPO Copyright Treaty (art. 10) and WIPO Performers and Phonograms Treaty (art. 16.2), as well as the pending European Union Information Society Directive (art. 5.4), increasingly adopt the "three-step test," the WTO Panel decision may significantly advance the development of a truly supra national law of copyright.

This article will analyze the Panel's interpretation of the test's three steps, and their application to the U.S.-law exemption (I). The article will also compare the Panel's treatment of the three-step test with the prior analyses proposed by several Berne Convention commentators, in order to reflect on what the Panel's analysis might mean for copyright exceptions more broadly (II). It is important to recognize, however, that the decision's actual impact on international copyright law will also depend on other considerations that will not be addressed here, including: Member State compliance with Panel decisions; the precedential effect of one Panel decision on later dispute resolution panels; and the willingness of national courts to look to WTO Panel decisions for guidance in evaluating local exceptions.

\section{The Panel's Decision}

The U.S. exemption that the Panel invalidated applied to the public performance of radio or television transmissions of non dramatic musical works by:

! any business establishment with less than 2000 gross square feet of space, and

! any food service or drinking establishment that has less than 3750 gross square feet of space,

! If the establishment is 2000 gross square feet or more, or if the food service or drinking establishment is 3750 gross square feet or more, the establishment will nonetheless be exempt, if : 
! the performance of the radio transmission incorporating nondramatic musical compositions is "communicated by means of a total of not more than 6 loudspeakers, of which not more than 4 loudspeakers are located in any 1 room or adjoining outdoor space," or

! the performance of a television transmission incorporating nondramatic musical compositions is "communicated by means of a total of not more than 4 audiovisual devices, of which not more than one audiovisual device is located in any 1 room, and no such audiovisual device has a diagonal screen size greater than 55 inches, and any audio portion of the performance or display is communicated by means of a total of not more than 6 loudspeakers, of which not more than 4 loudspeakers are located in any 1 room or adjoining outdoor space."2

The 1998 exception significantly enlarged a preexisting exemption, for the "communication of a transmission embodying a performance or display of a work by the public reception of the transmission on a single receiving apparatus of a kind commonly used in private homes ..."3 The EU also, but unsuccessfully, challenged this exception.

The EU contended that the U.S. section 110(5) exemptions violated U.S. TRIPs obligations because they conflicted with arts. 11(1)(ii) and 11bis(1)(iii) of the Berne Convention (incorporated through art. 9.1 of TRIPs). ${ }^{4}$ Art. 11(1)(ii) of the Berne Convention grants to authors of dramatic and musical works the exclusive right to authorize "any communication to the public of the performance of their works". Art. 11bis(1)(iii) grants to authors of artistic works (which includes nondramatic and other musical works) the exclusive right of authorizing "the public communication by loudspeaker or any other analogous instrument transmitting, by signs, sounds or images, the broadcast of the work". Art. 11bis(2) permits member countries to determine how the transmission right shall be exercised, but, in preserving the author's "right to obtain equitable remuneration," appears to preclude outright exemptions.

The US responded that the apparent inconsistency of section 110(5) with Berne Conv. arts. 11(1)(ii) and 11bis(1)(iii) did not constitute a violation of TRIPs because the exceptions came within the scope of TRIPs art. 13. As a threshold matter, this defense required the Panel to address the relationship between exceptions set forth in the Berne Convention, as incorporated in TRIPs, and the general TRIPs art. 13 exception. The EU had asserted that art. 13 should apply only to the rights newly introduced into TRIPs; it should not provide an additional or broader defense to a violation of a preexisting Berne Convention right. To expand the exceptions previously set out or implied into the Berne Convention would violate that Treaty's art. 20, which permits Union member countries to enter into agreements granting more extensive rights, but which, by implication, prohibits agreements reducing Berne Convention rights, argued the EU.

${ }^{2} 17$ U.S.C. $\S 110(5)(B)$.

${ }^{3}$ Id. $\S 110(5)(\mathrm{A})$.

${ }^{4}$ TRIPs art. 9 incorporates arts. 1-21 of the Berne Convention, with the exception of art. 6bis (moral rights). 
The EU further claimed that, under the Berne Convention, the disputed exception could not exceed the scope of the "minor exceptions" implied into the public performance right. ${ }^{5}$

The Panel determined that TRIPs art. 9.1 incorporated not only the Berne Convention text, but also its acquis, that is, the context of each provision's enactment, and their prevailing interpretations. Thus, the "minor exceptions" doctrine should be deemed incorporated as well. On the question whether the scope of TRIPS art. 13 exceeds the scope of "minor exceptions," the Panel agreed with the U.S. position that art. 13 "clarifies and articulates the standards applicable to minor exceptions under the Berne Convention" but does not enlarge it. ${ }^{6}$

Having equated performance rights "minor exceptions" with exceptions permitted under the three-step test, the Panel went on to assess the merits of $\S 110(5)$ in light of that test. The panel determined that $\S 110(5)(B)$ failed to meet any of the test's criteria .

\section{A. "Certain special cases"}

The Panel observed that the terms of art. 13 precluded exceptions of broad general application. The scope of the exception must be well-defined ("certain"), and narrowly limited ("special"). The Panel considered whether "special" also implied a requirement that a laudable public purpose underlie the exception, but declined to undertake the evaluation of local public policy that such an interpretation would compel. Rather, citing the determinations of other WTO adjudicative bodies, the Panel "rejected interpretative tests based on the subjective aims of the national legislation."7

The Panel emphasized that $\S 110(5)(B)$ 's broad business exception well exceeded "certain special cases" (by contrast, it deemed the "homestyle" exception sufficiently limited to meet this standard); the term "requires that a limitation or exception in national legislation should be clearly defined and should be narrow in its scope and reach." While $\S 110(5)(B)$ may be clearly defined, it could hardly be deemed "narrow" when, according to a studies quoted by the Panel, $73 \%$ of all eating establishments, $70 \%$ of all drinking establishments, and $45 \%$ of all retail establishments, fall below $\S 110(5)(B)$ 's size limits, and therefore benefit from the exemption. By contrast, 16\% of eating establishments, $13.5 \%$ of drinking establishments, and $18 \%$ of retail establishments benefitted from the "homestyle" exemption. ${ }^{8}$ Moreover, the scope of the "homestyle" exception was narrower as to the type of work: While the text of $\S 110(5)(A)$ states "a work," the Panel and

\footnotetext{
${ }^{5}$ The Berne Convention does not itself provide for "minor exceptions" or "minor reservations" to the public performance right. On "minor reservations," see generally, S. RICKETSON, THE BERNE CONVENTION: 1886-1986 II 9.63 (1987) [hereafter RICKETSON]; Panel decision IIII 6.47-66.

${ }^{6}$ Panel decision II 6.82. Accord Mihaly Ficsor, Copyright in the Digital Era: the WIPO "Internet" Treaties, 21 Colum.-VLA J. L \& Arts 197, 215 (1997) ("generally and normally, there is no conflict between the Berne Convention and TRIPs Agreement as far as exceptions and limitations to the exclusive rights are concerned," citing WIPO Publication No. 464(E) at 22-23.)

${ }^{7}$ Id. II 6.111.

${ }^{8}$ Id. IIII $6.102-153$.
} 
parties determined that, in context with $\S 110(5)(\mathrm{B})$ 's treatment of non dramatic musical works, the scope of $\S 110(5)(\mathrm{A})$ should be understood as limited to dramatic musical works. ${ }^{9}$ That limitation kept the $\S 110(5)(\mathrm{A})$ exception within the confines of narrow specificity required by the Panel's interpretation. ${ }^{10}$

The Panel rejected the EU's contention that the "homestyle" exception might significantly overflow its current contours, as equipment "commonly used in a private home" becomes increasingly sophisticated, and particularly if that equipment enables transmission over the Internet. ${ }^{11}$ The panel acknowledged the possibility that new technologies might render certain uses no longer "certain special cases," but stated that it was evaluating the current scope of the exception based on current technology. ${ }^{12}$ The Panel's refusal to take into account potential new technologies in assessing the scope of the exception should be contrasted with the Panel's assessment of the role of new technologies and new uses on the impact of the exception on the normal exploitation of a work.

\section{B. "That do not conflict with a normal exploitation of the work"}

The Panel first addressed whether the term "normal" was "empirical" or "normative," that is, whether it denoted the way in which the work is in fact exploited, or whether it (also) implied that the nature of the exploitation was potential, permissible or desirable. The Panel determined that both connotations were appropriate. ${ }^{13}$

On the empirical side, the U.S. argued that the Panel should not address individual rights in isolation, but the package of rights in the work as a whole. Because music right holders' principal remuneration comes from "primary" performance and broadcasting - such as live performance or payment from a broadcaster in order to transmit the work - and $\S 110(5)$ relates only to "secondary" broadcasts, the U.S. contended that retransmissions of radio broadcasts were insignificant compared to the "normal," i.e., dominant, exploitation of the work. ${ }^{14}$ The panel rejected this argument and agreed with the EU that each right must be considered in isolation. The panel emphasized that "possible conflict with a normal exploitation of a particular exclusive right cannot be counterbalanced or justified by a mere fact of the absence of conflict with a normal exploitation of another exclusive right, even if the exploitation of the latter right would generate more income." ${ }^{15}$ The Panel emphasized that the Berne Convention accords both primary

${ }^{9}$ See id. at III $2.7 ; 6.146$.

${ }^{10}$ Id. III 6.146-148.

${ }^{11}$ Id. III $6.137,6.150$.

${ }^{12}$ Id. II 6.153.

${ }^{13}$ Id. II 6.166.

${ }^{14}$ Id.II 6.168.

${ }^{15}$ Id. III 6.172-173. 
and secondary transmission rights (see arts. 11(1)(ii) and 11bis(1)(iii)), each of which may "normally" be exercised separately. The U.S. interpretation, however, would collapse the distinct rights, because it would disregard the conflict with individual rights, so long as exercise of the principal right were not compromised.

Turning to the "normative" connotation of "normal exploitation," the Panel looked to documents prepared for the 1967 Stockholm Revision Conference that drafted art. 9.2 of the Berne Convention. ${ }^{16}$ Citing a report of the Swedish government and BIRPI (Bureaux for the Protection of Intellectual Property, the predecessor organization to WIPO), the Panel indicated that the disputed exception "should not enter into economic competition" with the right holder: according to the report, "all forms of exploiting a work, which have, or are likely to acquire, considerable economic or practical importance, must be reserved to the authors." 17 "Thus," the Panel continued, "it appears that one way of measuring the normative connotation of normal exploitation is to consider, in addition to those forms of exploitation that currently generate significant or tangible revenue, those forms of exploitation which, with a certain degree of likelihood and plausibility, could acquire considerable economic or practical importance." 18

The Panel's cautious characterization of this test as "one way of measuring" the normalcy of an exploitation leaves open the possibility that other measures might also apply. The Panel emphasized in any event that not every commercial use of a work necessarily enters into conflict with a normal exploitation of it. ${ }^{19}$ Ultimately, the Panel stated:

We believe that an exception or limitation to an exclusive right in domestic legislation rises to the level of a conflict with a normal exploitation of the work . . if uses, that in principle are covered by that right but exempted under the exception or limitation, enter into economic competition with the ways that right holders normally extract economic value from that right to the work ... and thereby deprive them of significant or tangible commercial gains. ${ }^{20}$

The panel indicated that current licensing practices do not necessarily define the normal extraction of economic value. These practices would not afford a "sufficient guideline" if, for example, the law of the country at issue does not confer exclusive rights in a particular use, or where, "due to lack of effective or affordable means of enforcement, right holders do not find it

\footnotetext{
${ }^{16}$ The Panel also noted Professor Ricketson's characterization of a "normal exploitation" as covering "the ways in which an author might reasonably be expected to exploit his work in the normal course of events", II 6.176. We will return to Professor Ricketson's interpretation in Part II of this Article.

${ }^{17}$ Panel decision II 6.179, quoting Document S/1: Berne Convention; proposals for Revising the Substantive Copyright Provisions (Articles 1-20), prepared by the Government of Sweden with the assistance of BIRPI, p. 42 [hereafter "Stockholm Study"].

${ }^{18}$ Panel decision II 6.180.

${ }^{19}$ Id. IIII $6.181,6.182$.

${ }^{20}$ Id. II 6.183.
} 
worthwhile or practical to exercise their rights." ${ }^{21}$ This caveat suggests that a "normal exploitation" may be an idealized one: if the exploitation falls within the scope of the copyright, and no copyright or related cultural policies undergird the right holder's disability from exercising the right, then the exploitation may, as a normative matter, be "normal." Significantly, the Panel declined to assess the "normalcy" of the exploitation in the disputed country by reference to the exercise of rights in other economically-comparable WTO countries. The Panel did not foreclose that kind of analysis; it simply found it unnecessary in the case before it. ${ }^{22}$

Applying the "economic competition" standard, the Panel ruled the $\S 110(5)(\mathrm{B})$ business exemption impermissible. The Panel observed, inter alia, that rights owners license business establishments to play live and recorded music, while $\S 110(5)(B)$ eliminates the basis for licensing the same establishments with respect to performing works via broadcast radio and television. If the market as a whole is music performed in business establishments, then the exemption of broadcasts significantly compromises the copyright owner's opportunity for commercial gain. Even were the markets separated into live and prerecorded music on the one hand, and broadcasts on the other, the exemption for broadcasts competes with the exploitation of the other market because it provides business establishments an incentive to shift from paying modes of exploitation to exempt modes of exploitation. ${ }^{23}$

By contrast, the Panel held that the $\S 110(5)(\mathrm{A})$ homestyle exception did not "conflict with a normal exploitation of the work" because it appeared to the Panel to be of little economic or practical importance. ${ }^{24}$ The exception covered only a small percentage of establishments, and, according to the interpretation acknowledged by both the U.S. and the E.U., reached only dramatic musical works. The panel also observed that in the U.S., collective licensing societies do not administer the public performance rights in dramatic musical works; as a result, right holders do not normally license the right to retransmit broadcast performances of dramatic works to the small establishments covered by the homestyle exception.

\section{C. "And that do not unreasonably prejudice the legitimate interests of the right holder"}

At the outset of its analysis of the third step, the Panel observed that three terms required definition: "interests," "legitimate," and "unreasonable." The Panel determined that "interests" need not be "limited to actual or potential economic advantage or detriment." 25 The panel thus may have left the door open to non economic considerations (despite the exclusion of Berne

\footnotetext{
${ }^{21}$ Id. II 6.188.

${ }^{22}$ Id. II 6.189.

${ }^{23}$ Id. II 6.209-211.

${ }^{24}$ Id. IIII 6.212-219.

${ }^{25}$ Id. II 6.223.
} 
Conv. art. 6bis from TRIPs incorporation); the current controversy, however, implicated only economic interests.

As for "legitimate," the Panel adduced both a "legal positivist" perspective (authorized or protected by law), and "a more normative perspective, in the context of calling for the protection of interests that are justifiable in the light of objectives that underlie the protection of exclusive rights." ${ }^{26}$ Although the Panel did not further elaborate on the normative content of the right holder's "legitimate" interests, one might suppose that, for example, censorship would not be one of these. Thus, an author would not have a "legitimate" interest in preventing publication of an unfavorable book review: an exception that allowed quotations for purposes of criticism would therefore not harm the author's "legitimate"interests, even if the resulting book review depressed the book's sales. The $\S 110(5)$ controversy, it bears emphasis, concerned a pork barrel exemption purely for the benefit of certain business consumers of copyrighted works; it did not implicate any of the free speech or scholarship interests that underlie many other copyright exceptions. As a result, the Panel decision does not purport to offer guidance toward analyzing the "legitimacy" of right holder interests when they are confronted with the creative interests of other authors.

With regard to tolerable levels of "prejudice," the Panel noted that the text's formulation, "not unreasonably prejudice" "connotes a slightly stricter standard" than "reasonable." 27 While acknowledging that the treaty text permits copyright owner's interests to undergo some prejudice, the Panel determined that the prejudice would reach an "unreasonable" level "if an exception or limitation causes or has the potential to cause an unreasonable loss of income to the copyright owner." 28 Citing the "persuasive value" of the WIPO Guide to the Berne Convention, the Panel noted that the prejudice might be brought back to tolerable levels were compensation at least provided: "in cases where there would be a serious loss of profit for the copyright owner, the law should provide him with some compensation (a system of compulsory licensing with equitable remuneration)." 29 The U.S. exception, however, imposed an outright exemption, it did not offer any compensation.

Applying these standards to $\S 110(5)(\mathrm{B})$, the Panel rejected the U.S. argument that there was no "unreasonable" prejudice because, as a result of collective licensing of radio and television transmissions, right holders already received compensation for primary transmissions. The U.S. had endeavored to characterize the secondary transmissions effected by business establishments as incidental, and therefore too insignificant for their exemption to be deemed "unreasonable." The Panel, however, emphasized the distinct nature of each exclusive right; thus the retransmission right under Berne Convention art. 11bis(iii) must be considered separately from the public communication right under art. 11(1)(ii). In evaluating the prejudice, the Panel did not limit itself to the loss actually suffered by EU copyright owners. The U.S. had calculated that the maximum

${ }^{26}$ Id. II 6.224.

${ }^{27}$ Id. II 6.225 .

${ }^{28}$ Id. II 6.229.

${ }^{29}$ Id. II 6.229 n. 205. 
effect of the $\S 110(5)(\mathrm{B})$ exemption was to reduce the licensing income by less than $5 \%$, a de minimis and therefore reasonable amount, according to the U.S. The Panel instead emphasized that it was necessary to take into account not only current losses (which, might, indeed, have been deemed "reasonable") but also potential losses. The Panel ruled that the party asserting the legitimacy of the exception bore the burden of proof of reasonableness, and that the U.S. had not made a convincing showing that the potential harm would not be "unreasonable." 30 By contrast, the Panel accepted the homestyle exception because it exempted only a relatively small number of establishments, and the evidence showed that secondary transmissions of dramatic works were not a significant source of income for right holders. ${ }^{31}$

\section{The Panel Decision's Analysis in Light of Other Interpretations of the Three Step Test and Its Broader Implications for Copyright Exceptions}

Under the Panel's decision, to survive scrutiny under TRIPs art. 13, the member state defending the challenged exemption or limitation bears the burden of showing:

(1) That the exemption is limited to a narrow and specifically defined class of uses ["certain special cases"], but the member state need not demonstrate or justify the local policy that underlies the exception;

(2) That the exempted use does not compete with an actual or potential source of economic gain from the ways right holders normally exercise rights under copyright [“conflict with a normal exploitation of the work"]; and

(3) That the exempted use does not unreasonably harm right holder interests that are justifiable in light of general copyright objectives ["not unreasonably prejudice the legitimate interests of the rightholder"]; the unreasonableness of the harm may be allayed if the member state imposes a compensation-ensuring compulsory license in lieu of an outright exemption.

Let us now compare the Panel's approach with the analyses offered by the leading commentators of the Berne Convention. By elucidating where the Panel decision comports with, and where it departs from, leading commentators, we hope to sharpen the analysis of the Panel decision's implications for other copyright exceptions. Reference to Berne Convention commentators is warranted because the three step test in TRIPs art. 13 derives from art. 9(2) of the Berne Convention. Art. 9(2) was the counterpart to the art. 9(1) right of reproduction introduced into Berne in the 1967 Stockholm Revision, and adopted in the 1971 Paris Act. Although most countries in the Berne Union recognized the right of reproduction before the right's Stockholm codification, Union members provided for different exceptions to the scope of the right. As a result, the Stockholm drafters confronted the task of devising guidelines that

\footnotetext{
${ }^{30}$ Id. IIII 6.327-266.

${ }^{31}$ Id. গIII 6.267-272.
} 
would pose meaningful constraints on the creation of exceptions, yet accommodate existing member state exceptions. ${ }^{32}$ Not surprisingly, this effort sparked extensive debate and revision of the proposed text. ${ }^{33}$

Before the WTO Panel decision, no adjudicative body had construed the meaning of art. 9(2). As for the provision's "legislative history," we have seen that the Swedish/BIRPI Study Group that proposed the first version of what ultimately became art. 9(2), focused on the "economic competition" that the exempted use would pose to the copyright holder. In his 1987 treatise, The Berne Convention: 1886-1986, Professor Ricketson extensively reviewed other preparatory documents in an effort to articulate the meaning of art. 9(2). As the leading authority on the Berne Convention, Professor Ricketson's interpretation of the three-step test merits particular attention. The WTO Panel also noted the "persuasive value" of the 1978 WIPO Guide to the Berne Convention, authored by Claude Masouyé, then-Director of WIPO's copyright division. In comparing the Panel's analysis with that of other commentators, we will also take account of another important source for interpreting the three-step test: the 1976 treatise by Desbois, André Françon, and André Kéréver, Les Conventions Internationales du Droit d'Auteur et des Droits Voisins.

\section{A. "Certain special cases"}

Of the three commentators discussed here, only Professor Ricketson proposes a detailed analysis of the first step. He offers a two-part reading. First, the exception must be for a specific purpose; exceptions covering a broad range of subject matter or of uses would not be permissible. Second, an exception must be justified by some "clear reason of public policy or some other exceptional circumstance." 34 As we have seen, the Panel decision rejected the second interpretation. $^{35}$ The drafting history of art 9(2) is scant on this point. Professor Ricketson quotes some of the alternative terminology submitted during the drafting process: the terms "particular" and "specific" appear in some drafts in lieu of "special." 36 Arguably, the term "special" carries more normative connotations than "particular" or "specific." In the absence of a record of debate on the choice of "special," however, it is not apparent that the drafters intended to incorporate a policy justification into the first step of the test.

Moreover, the drafting history regarding "normal exploitation" suggests that "certain special cases"does not necessarily have a normative dimension. As the Panel decision explains in its analysis of the second step, the term "normal exploitation" was understood to accommodate the perpetuation of the accretion of local exceptions already in place at the time of art. 9's

\footnotetext{
${ }^{32}$ RiCKETSON, supra, II 9.2

${ }^{33}$ Id. IIII 9.3-5.

${ }^{34}$ RICKETSON, II 9.6.

${ }^{35}$ Panel decision IIII 6.111-112

${ }^{36}$ RICKETSON, SIII 9.3-9.5
} 
adoption. ${ }^{37}$ Although the Stockholm study quoted by the Panel referred to "domestic laws already contain[ing] a series of exceptions in favour of various public and cultural interests," 38 it is not clear that all of these exceptions could in fact claim persuasive policy underpinnings. Because art. 9(2) creates a hierarchy of analysis - that is, step one is the threshold to be crossed before analysis of the other criteria may be undertaken - an adjudicator would not need to reach the question of "normal exploitation" if the "certain special cases" condition were not satisfied. ${ }^{39}$ As a result, if the drafters were positing compatibility of preexisting national exceptions with "normal exploitation," they must have assumed the exceptions qualified as "certain special cases." If not all those preexisting exceptions could boast a strong policy justification, then "special cases" can include unworthy as well as laudable exceptions, so long as they are sufficiently narrow. The normative inquiry is deferred to the second two steps.

Finally, in the opinion of this writer, the Panel decision correctly eschewed inquiry into the motivation for a particular exception. The record of the 1967 and 1971 Acts does not clearly preclude pork barrel-type exceptions (if they are sufficiently discrete), and the WTO may be illsuited to condemn local giveaways of this kind. Recall that no exemption, however worthy the policy underlying it, will survive scrutiny if it "conflicts with a normal exploitation" or "unreasonably prejudices the legitimate interests of the right holder." If there are trade distortions, they will arise from non compliance with the second or third steps. It is not clear that a dubious purpose, standing alone, would give rise to a trade distortion. By rejecting a normative component to the first step, the Panel avoided embroiling itself in evaluating the merits of local policy determinations (or of local concessions to powerful lobbies). Exercising diplomatic caution in this case, moreover, does not undermine the essential inquiry, since bad consequences of bad policy decisions may be redressed through application of the second and third steps.

\section{B. "Normal exploitation"}

All three commentators address the second step. Professor Ricketson posits that "common sense" indicates that "normal exploitation" refers simply to "the ways in which an author might reasonably be expected to exploit his work in the normal course of events." There are some uses an author would not normally expect to be paid for, even though they fall within the literal scope of the right, for example, copying a work for use in court proceedings. Receiving payment for these kinds of uses therefore would exceed the work's normal exploitation. The normalcy of the exploitation, however, may depend on the nature of the work at issue. ${ }^{40}$ In a later commentary, Professor Ricketson further indicates that there might be no

\footnotetext{
${ }^{37}$ Panel decision II 6.181.
}

${ }^{38}$ Stockholm study, supra note 17 , at 41 .

${ }^{39}$ See Panel decision II 6.160, observing that its finding that $\S 110(5)$ (B) fails the first step suffices to hold the U.S. in violation of art. 13 on this ground, but determining that because $\S 110(5)(\mathrm{A})$ satisfied the first step, it would be necessary to reach the second and third steps for $\S 110(5)(\mathrm{A})$; given the close relationship between $\S \S 110(5)(\mathrm{A})$ and (B), the Panel concluded that it would apply its analysis of the last two steps to $\S 110(5)(B)$ as well.

40 RICKETSON, II 9.7. 
conflict with a normal exploitation when "there is no realistic possibility that the copyright owner would be able to enforce her rights, either by way of refusing permission or obtaining a fee by free negotiation ..."41 This suggests that the "normal" exploitation of a work may change with technology or other developments. Uses whose control once presented excessively high transaction costs might today or tomorrow be more susceptible to effective licensing, and therefore might enter the fold of "normal exploitations." 42 This kind of analysis shows, however, as Professor Paul Goldstein has remarked, that "an obvious circularity underlies" the "normal exploitation" criterion. "At least historically, an author will normally exploit a work only in those markets where he is assured of legal rights; by definition, markets for exempted uses fall outside the range of normal exploitation. Consequently, it might be thought that to expand an exemption is to shrink the "normal market,' while to expand the definition of 'normal market' is to shrink the permitted exception." 43

Professor Goldstein would avoid this "logical paradox" by reference to the WIPO Guide's approach, which appears to privilege the current or anticipated principal means of producing and vending particular kinds of works (the example given in the WIPO Guide is the printing and sale of novels and school books; Professor Goldstein suggests that the marketing of audiovisual works on DVD is another, even if little such marketing has yet occurred today). ${ }^{44}$ The WIPO Guide otherwise offers little analysis of what constitutes a "normal" exploitation. The WIPO Guide emphasizes that if the exception conflicts with a normal exploitation, it is impermissible. As a result, the compromise measure of compulsory licensing, which comes into play when there is no conflict with a normal exploitation, but when the exception unreasonably prejudices the author's legitimate interests, would not be appropriate.

The Desbois, Françon, Kéréver treatise also stresses that absence of conflict with a normal exploitation is a "sine qua non -- only if this condition is satisfied is there reason to concern oneself with whether the [third] is satisfied or not." 45 This treatise does not substantially elaborate on the meaning of "normal exploitation," however, except by way of an example comparing "normal exploitation" with "unreasonable prejudice." The treatise suggests that photocopying large numbers of copies would conflict with a normal exploitation; systematic,

\footnotetext{
${ }^{41}$ Sam Ricketson, Interational Conventions and Treaties, in LIBBy BAULCH, MichaEL GREEN AND MARY WybuRn, EDS., THE BOUNDARIES OF COPYRIGHT, ITS PROPER LIMITATIONS AND EXCEPTIONS 10-11(ALAI Study Days, Cambridge, 14-17 September 1998)(1999). He also cautions that in those instances, an exception for the use "would clearly be caught by the third criterion ..." and therefore should be subject to compulsory licensing.

${ }^{42}$ See, e.g., American Geophysical Union v. Texaco, Inc., 60 F.2d 913 (2d Cir. 1995)(contrasting difficulty of administering photocopy rights in mid-seventies with relative ease of licensing in mid-nineties).

${ }^{43}$ Paul Goldstein, InTERnational Copyright: PRINCIPLES, LAW AND PRACTICE $§ 5.5$ (2001).

${ }^{44}$ Claude MasouyÉ, Guide to the Berne CONVENTION For the Protection OF LiteraRy AND ARTiSTIC WORKS, [hereafter WIPO GUIDE] at II 9.7 (1978).

${ }^{45}$ Henri DESBois, ANDRÉ FranÇOn AND ANDRÉ KÉRÉVER, LES CONVENTIONS INTERNATIONALES DU DROIT D’AUTEUR ET DES DROITS VOISINS II 173 (1976).
} 
institutional photocopying of single copies would not conflict, but could unreasonably prejudice the author's legitimate interests, and therefore could be made subject to a compulsory license. ${ }^{46}$

These sources' inquiry into the "normalcy" of the exploitation appears to focus primarily on what the Panel called the "empirical" aspect of the term "normal exploitation." The issue seems to be whether today the right owner is, or tomorrow will be, in fact exploiting a particular market. Most do not clearly confront the "normative" dimension that the Panel further perceived in the second step, although Professor Ricketson's reference to "the ways in which an author might reasonably be expected to exploit his work" (emphasis supplied) hints at a normative, as well as an empirical, criterion. That said, having announced the existence of a normative dimension, the Panel did not clearly articulate its content. In fact, the Panel's suggestion that one might discern the normative connotations of the second step by considering "those forms of exploitation which, with a certain degree of likelihood and plausibility, could acquire considerable economic or practical importance, ${ }^{47}$ seems more like a direction to anticipate what the empirical situation will be, than an explanation of what the right holder's markets should cover. Admittedly, as observed earlier, the case before the WTO Panel did not present significant normative difficulties, since the pork barrel exception at issue did not further speech, scholarship, or other creative activities often fostered by copyright exceptions.

The absence of a genuine normative problem could lead one to oversimplify the synthesis of the Panel decision and other authorities. Arguably, any economically significant exploitation that the right holder realistically can, or will be able to, individually license comes within the scope of a "normal exploitation." So stated, however, there is a risk that even traditionally privileged uses, such as scholarship or parody, could be deemed "normal exploitations," assuming copyright owners could develop a low transactions cost method of charging for them. It is not sufficient to reply that the desirability of charging for these uses may be addressed as part of the step three inquiry into the "legitimate" interests of the author: the authorities agree that one does not get to step three if the exception conflicts with a "normal exploitation." As a result, it is all the more important to bear in mind the factual context of the Panel decision. Should a controversy requiring examination of a speech- or scholarship-motivated exception under the three-step test come before a WTO Panel, or, for that matter, a member state court, that institution should consider whether, as a normative matter, there is a "market" for criticism and similar kinds of uses that the copyright owner should control. ${ }^{48}$

The predominantly economic focus of the Panel's analysis may be very useful in evaluating "market failure" and similarly economically-motivated exceptions, but still may prove too much, if the result is to outlaw the exception entirely, rather than remitting it to review under the more conciliatory third step of the test. Consider, for example, private copying. If de

\footnotetext{
${ }^{46} \mathrm{Id}$.

${ }^{47}$ Panel decision If 6.180.

${ }^{48}$ Cf. Campbell v. Acuff-Rose Music, Inc, 510 U.S. 569 (1994) (“no market” for parodies, even if copyright owner could license them).
} 
minimis impact or practical unenforceability have historically justified private copying exceptions, then modern technology considerably belies both premises. Were those the only justifications, then one would be tempted to conclude that private copying exceptions today conflict with a normal exploitation. If they so conflict, then there should be no private copying exception, even alleviated by a compulsory license. Were there also a non economic motivation for the exception, by contrast, it would be appropriate to develop the neglected normative dimension of "normal" exploitation. Suppose that justification were privacy or personal autonomy; one might contend that an author may not "reasonably be expected to exploit his work" in a manner that intrudes on end-user (as opposed to intermediary) autonomy. Of course, this argument threatens to prove too much the other way; it does, nonetheless, open the door to further inquiry under the third step.

\section{C. "Unreasonably prejudice legitimate interests"}

The authorities agree that the third step specifies "unreasonable" prejudice, because some prejudice will flow from any exception. ${ }^{49}$ While the text of art. 9(2) does not refer explicitly to compulsory licenses, the preparatory documents and the commentators concur that the harm may be rendered "reasonable" if the author is equitably compensated, including by means of a compulsory license. ${ }^{50}$ This does not mean that every exception should entail a compulsory license. Compulsory licenses that "conflict with a normal exploitation," for example, that pricefix where the market would otherwise permit transactional licensing, and that lack sufficient non economic justification, should fail the second step. ${ }^{51}$ By the same token, some exceptions will cause so little prejudice that the compromise measure of a compulsory license would not be required.

"Reasonableness" here appears to be an economic criterion. The Panel also alluded to normative criteria in its evocation of the "legitimate interests" of the right holders, but the commentators examined here do not directly discuss this component of the third step. As a general matter, the same normative concerns that advocated against a purely economic evaluation of "normal exploitation" should similarly inform the analysis of whether the right holder's interests are "legitimate." The "general copyright objectives" that the Panel evoked certainly include solicitude for the creativity of second authors. Hence the illegitimacy of an author's interest in silencing criticism. Where the author's interest is not legitimate, it appears that no compensation is owing, even by means of a compulsory license.

But what should the analysis be when the legitimacy of the author's interest may vary with the intensity with which it is asserted? That is, the author may have a legitimate interest in

49 RICKETSON, II 9.8; WIPO GUIDE II 9.8; DESBOIS II 173.

${ }^{50}$ Id. See also Actes of the Stockholm Conference, vol. II, n. 85, p. 15, quoted in DESBOIS, supra..

${ }^{51}$ Query, for example, whether this should be the case for the U.S. compulsory license for mechanical reproductions of musical compositions, see 17 U.S.C. § 115. 
being paid for the use; she may have a less legitimate interest in preventing it altogether. ${ }^{52}$ In that event, the legitimacy criterion seems to collapse into the "reasonableness" inquiry, at least where the author's interests are economic. Again consider private copying. Authors do have "legitimate interests" in stemming private copying, particularly in the digital environment, given its proclivities to massive multiplication of "private" copies. Indeed, an exception for large-scale "private" copying of the "sharing" type might well conflict with a normal exploitation (assuming the copyright could be enforced in this kind of situation). But if the copying remained truly private, rather than "shared," there may be a countervailing legitimacy to consider (even if, in this writer's view, enhancing the convenience of consumptive end-users is not a "general copyright objective"). This suggests that the third step may reduce to a balancing of the legitimacy of the interests of the right holders and of the beneficiaries of the exception. Where the right holder's interests significantly outweigh the beneficiaries', the exception should be prohibited; where the interests appear more or less balanced, a compulsory license may be imposed, and where the beneficiaries' interests significantly outweigh the right holder's, an outright exemption should be allowed.

Balancing tests are, however, notoriously imprecise, and tend to be more of a common law than a civilian adjudicative method. That does not recommend them as a supra-nationally or multi-nationally acceptable mode of analysis. That said, the reasonableness (if not also the legitimacy) criterion of step three by its own terms requires some weighing of conflicting interests; whether or not the prejudice is "reasonable" must be appreciated by reference to other values. Ultimately, analysis of the three step test will lead the adjudicator from the rather straightforward criteria of the first step, to the potentially manipulable "normal exploitation" second step, to the interpretative uncertainties of the "reasonableness" inquiry. As a result, the Panel decision may have clarified the terms of reference, but it may not have made future outcomes any more predictable.

\footnotetext{
${ }^{52} \mathrm{Cf}$. Campbell v. Acuff-Rose, supra note 48, at n. 10 (suggesting that were a parody found to have copied too much to be "fair use," a court might nonetheless decline to enjoin its distribution, in favor of awarding damages i.e., a de facto compulsory license - to the plaintiff).
} 